\title{
The Ethics of Study Abroad: Costs and Benefits
}

\author{
KRISTIN NELSON \\ University of Florida
}

\author{
JAMES LEACH \\ University of Florida
}

\begin{abstract}
Following the recent experience of teaching in a study abroad program for the first time, the authors set out to better understand the costs and benefits of this common educational model in schools of architecture. The primary goal is to compare the educational and intellectual benefits of study abroad for the student against the ecological, economic, and sociocultural costs incurred. This paper examines the ethical issues associated with engaging in extended international travel for primarily educational purposes, and seeks to consider potential adjustments to ameliorate the negative impacts of such activities.
\end{abstract}

\section{THE TRADITION OF THE GRAND TOUR(IST)}

The tradition of study abroad as an educational tool for students of architecture is a long one. Andrea Palladio visited Rome multiple times in the mid-fifteen hundreds at the beginning of his career, and continued to revisit the city to study, first-hand the architectural masterpieces of antiquity. This tradition of educational travel solidified in the later sixteenth century into the institution of the Grand Tour, in which young aristocrats aspiring to enlightenment and good taste would undertake extended travel to the cultural capitals of Europe. Common visits included Paris, Venice, Florence and Rome to see the cannon of great artistic and architectural works. This exposure was intended to prepare the travelers for a lifetime of informed patronage of the arts and architecture, and possibly to even participate in the design of their own country homes and gardens. Typically a full entourage of servants and a knowledgeable guide would accompany the traveler. In a time when travel was difficult, time-consuming and costly, the Grand Tour was the province of a few wealthy elites - the "one percent" in contemporary terminology.

\section{THE ETHICS OF ACCESS}

The tradition of the Grand Tour has evolved into the modern study abroad program. The technology of travel has advanced substantially from the days of the Grand Tour, reducing the time required for travel and the financial cost incurred. This new standard has lowered the barrier to study abroad significantly, allowing a more diverse cross-section of students to participate. Study abroad is an option commonly available to students at many American schools of architecture. The Association of Collegiate Schools of Architecture website maintains a by no means exhaustive list of 41 member institutions that offer study abroad programs in their architectural curriculum. ${ }^{1}$ In recent data from the National Center for Education Statistics, the number of study abroad students in all post-secondary education has increased from approximately 100,000 students in 1996-1997 to just over 300,000 students in 2013-2014. ${ }^{2}$ Also, the distribution of student gender shows that female students are very well represented, making up nearly two-thirds of all study abroad participants for all years listed in the study. ${ }^{3}$ These two figures imply an experience that is much more inclusive than the rarified Grand Tour of young gentlemen. Continuing through the table, however, the news becomes less positive. When examining the participants by race, white students make up nearly $75 \%$ of the participants in the latest year and over $80 \%$ until the 2008-2009 data. ${ }^{4}$ Students self-identifying as black are particularly underrepresented, making up just over $5 \%$ of participants in the most current year data for 20132014 , and making up between $3.4 \%-3.5 \%$ of participants in years 2000-2006. ${ }^{5}$ When compared with the population of self-identified black students attending post-secondary education in 2013-2014, making up 14.5\% of all students, these students are particularly underrepresented in study abroad opportunities. ${ }^{6}$

Examining the overall participation in study abroad opportunities, there were $20,207,369$ students attending post-secondary schools in the United States in 2013-2014. ${ }^{7}$ In this same year 304,467 students participated in study abroad. ${ }^{8}$ Comparing these two numbers suggests that something like $0.02 \%$ of students enrolled in a post-secondary education program participated in a study abroad experience. All of the nobles in 18th-century Europe numbered perhaps 3-4 million out of a total of 170-190 million inhabitants, or approximately $0.02 \%$ of the population of the continent. Certainly all of the nobles in eighteenth century Europe were not undertaking the Grand Tour in a given year. That being said, examining the low participation figure for current study abroad opportunities amongst the already limited pool of students attending post-secondary education suggests that further consideration for the accessibility of the study abroad experience is necessary.

In 2013-2014 the average yearly cost of attendance at a public institution, including tuition, fees, room and board was $\$ 15,745$, and the average student earns a bachelor degree in just over five academic years. ${ }^{9}$ This means that the average student will graduate with degree cost of approximately $\$ 79,000$. This cost is, of course, offset for many students by grants and scholarships, and many also work at part-time jobs or work-study jobs to pay portions of their tuition as 
they attend. The average student loan debt for students in 2014-2015 in the United States is $\$ 37,000 .^{10}$ The average cost of a study abroad semester is $\$ 31,270$, or double the cost of an average year of tuition. These numbers demonstrate the considerable financial burden a student must be willing and able to take on to participate in a study abroad experience.

\section{THE EDUCATIONAL VALUE OF STUDY ABROAD}

Among the benefits commonly attributed to study abroad experiences, most are soft skills including: building language skills, becoming more independent, developing international relationships and networks, broadening cultural awareness and sensitivity, and becoming more prepared to navigate a globalized world..$^{11} 1213$ These benefits sit squarely within the aims of a liberal arts education. In this way, study abroad may be of greater-than-average value to undergraduate students of architecture and other professional schools, whose heavy course loads tend toward a strong focus on topics related to their primary study, often at the expense of a traditional liberal arts curriculum. Study abroad specifically offers architecture students the ability to experience great architectural works, as Juhani Pallasmaa advocates, with "the body as locus of perception," in-person, in real-time, warts-and-all. ${ }^{14}$ This multi-sensory, contextual experience is an invaluable supplement to the more limited experience of an architectural work as seen only through the curated images that are used in the classroom and the studio. Study abroad further offers the experience of cultural immersion that is difficult to access in any other way. Anecdotally, it was made clear in student comments throughout the journey that the immersive experience of our travels engendered in the students an intense interest and deeper enthusiasm for the practice and evaluation of architecture.

\section{THE ECONOMIC AND SOCIOCULTURAL IMPACTS OF TOURISM}

From the program base in Northern Italy, extended visits were made to three major European cities: Venice, Rome, and Barcelona, during the semester. Significantly, all three of these cities are major tourist destinations and are experiencing an ever-increasing number of tourists - currently amounting to over 30 million tourists per year in each city. ${ }^{15}$ 1617 This additional mass of non-residents leads to various adverse effects. The most obvious tourist-related problems are increased traffic and overcrowded streets and cultural sites, squeezing locals out of large portions of their own cities and leading to damage and degradation of the physical and cultural fabric of the city. The majority of the blame is assigned to "mass tourism" or "fast tourism" in the form of cruise ships and large organized tour groups marching through the city, led by an amplified tour guide.

The primary argument in defense of tourism, despite any negative impacts, is that tourism injects outside money into local economies. This is a valid point. In fact, tourism accounts for over $11 \%$ of Italy's GDP. What this number does not reveal, is that much of this economic windfall benefits large conglomerates that own hotels and real estate, rather than the average local. The tourism economy does create employment opportunities, but these low-wage, long-hour jobs are not careers that support a high quality of life. Tourist dollars and the sharing economy also distort real estate costs and rental rates. With an effect similar to gentrification, these pressures drive up prices and drive long-term local residents and small business owners out of the market.

\section{VENICE: THE POSTER CHILD OF TOURISM'S ILL EFFECTS}

Venice provides perhaps the most extreme illustration of the ills that tourism can bring. Increases in the cost of living, particularly housing costs, and a decrease in quality of life, with tourists and low-quality tourist-focused businesses driving out locals and local businesses, has resulted in a decrease in Venetian residents from 174,808 inhabitants in 1951, to just 54,976 in $2016 .{ }^{18}$ This tremendous loss of inhabitants, a $68 \%$ decrease, is comparable to the population loss that Detroit, Michigan has experienced over the same time period. ${ }^{19}$ The desirability and over-consumption of Venice as a tourist destination has, ironically, led to the same impact on population that economic collapse created in Detroit.

While the effects of population loss in Detroit are clearly visible in empty storefronts and vacant lots, the population loss in Venice is masked by the force that is creating the problem. Many of Venice's 30 million yearly visitors arrive on large cruise ships for shore excursions. These enormous ships hold over 5,000 passengers and dock in the center of the city. They discharge their entire passenger manifest into the city, often for a period of a few hours on a day tour, before reversing the process to reload the ship. This enormous influx of humanity clogs the main streets leading to the Rialto Bridge and St. Mark's Square. Thousands of tourists struggle to move through the small, pedestrian bridges and the intimate sidewalks of the city, and residents simply avoid these areas as much as possible. Just the physical presence of the huge ships has considerable environmental consequences. Their size necessitates deep dredging of the lagoon, and their fuel pollutes the water and air. Their passage displaces huge amounts of water, eroding the surrounding mudflats, causing sediment loss, and wearing at the foundations of the city's historic buildings. ${ }^{20}$

Many local associations and environmental groups like Italia Nostra and Venice in Peril have staged protests and demonstrations, pointing out the harm of tourism and advocating various measures for limits and controls, but to date no clear plan has emerged. The situation is so dire that both the World Monuments Fund and UNESCO have officially expressed deep concerns over the environmental and social damage that cruise ships and mass tourism are causing in the city and have threatened to de-list Venice. ${ }^{21}$ 


\section{BARCELONA: LOCALS FIGHT BACK}

During our travels, it became clear through media and firsthand experience that in Rome, Venice, and particularly in Barcelona, many local residents held very strong anti-tourist sentiments. In Barcelona anti-tourist stickers and posters were common in businesses in neighborhoods off the touristbeaten path. Our Spanish-speaking students found the local in these neighborhoods happy to speak English but reluctant to use Spanish.

Many of the residents of Barcelona perceive tourism as a net negative impact to their communities. The financial pressure that tourism puts on locals is a significant source of this disquiet. Despite Barcelona's much larger size and population of 1.6 million, the presence of 30 million visitors per year has caused a steep rise in rents. In a recent survey, locals identified tourism as the city's second biggest problem, after unemployment. ${ }^{22}$ In response, an outspoken anti-tourist movement has developed. Two thousand discontented residents staged an occupation of La Rambla, the main tourist street of the historic center of Barcelona in January 2017, marching behind a huge banner stating that "Barcelona is Not for Sale. ${ }^{23}$ Some anti-tourist parties have gone so far as to attack a tourist bus and destroy bicycles rented to tourists. ${ }^{24}$ Unlike in Venice, however, local government has begun to respond. For the first time, the Barcelona city council recently passed laws to limit tourism, stopping the building of new hotels and limiting the licensing for tourist apartments. ${ }^{25}$ Furthermore, the city has developed a tiered planning strategy to consolidate tourist accommodations in designated parts of the city while strictly limiting them in "local" residential neighborhoods.

\section{ROME: LANDMARKS AT RISK}

Like Venice and Barcelona, Rome sees a huge number of yearly visitors, and has similar struggles with adverse economic impacts on locals, as well as traffic and overcrowding. In fact, problem behavior by tourists has spurred city authorities to impose bans on sitting, eating or paddling in the city's fountains and drinking on the street at night. Rome also holds one of the greatest concentrations of cultural and artistic treasures in the Western World. One historic site in Rome provides a vivid illustration of the threat that mass tourism can pose to these landmarks.

Controversy broke out in 2012 in response to an article written for the 500 year anniversary of the Sistine Chapel. In the Corriere della Sera, Pietro Citati, an Italian critic advocated for limiting tourist numbers to preserve the dignity and the physical material of Michelangelo's masterpiece. ${ }^{26}$ Citati decried the "herds" of tourists - 20,000 visitors per day, adding up to more than five million visitors each year - that pack in to the Sistine Chapel in a scene that a security guard described as "just like a street market."27 The resulting noisy and chaotic environment is ill-suited to the original goals of fostering religious contemplation and appreciation of the art for obvious reasons. Moreover, the elevated levels of dust, heat, humidity and carbon dioxide created by the overcrowding represent a serious risk to the artwork, depositing a layer of grime on the surfaces of the frescoes and requiring ongoing conservation work. A Vatican representative admits that the current situation is problematic, but rejects the notion of placing tighter limits on the crowds as "unthinkable."28 Characterizing such a move to a regression to the elitist past, the Vatican put forth an alternative plan to overhaul the climate control system in the Sistine Chapel to include aggressive cooling, dehumidification and dust extraction measures. ${ }^{29}$ Whether these mechanical measures are adequate to protect the material of the frescoes remains to be seen. What is known is that they will do nothing to improve the experience of viewing the over-burdened consecrated space that has been likened by many to a busy train station.

\section{MASS TOURISM - AN OBJECT LESSON?}

The possibility presents itself, that rather than ignoring the issues surrounding the impacts of mass tourism, our (or any) architectural study abroad program might be the perfect vehicle to address these issues head-on. Study abroad gives design students the opportunity to experience, first-hand, the forces at play and the effects on communities. By anticipating and embracing these experiences, study abroad curriculum could be set up to frame these issues through readings and discussions, and potentially to grapple with them in the context of design projects.

\section{THE ETHICS OF ENERGY, CARBON AND WASTE}

Some of the impacts of tourism on the local environment, particularly in Venice, have already been demonstrated. There are other, less immediate and visible effects that should be considered. The calculations for this portion of the paper were completed on the University of California, Berkeley Cool Climate Network online calculation tool. ${ }^{30}$ Each portion of travel is entered into the calculator, which yields a result in tons of carbon dioxide. The results are summarized in the figure below. For the sake of simplicity, we used our own situation as a case study to consider the impact that a study abroad experience has on energy and carbon footprint. As noted below, our particular living experiences will differ substantially from the average in some regards, and may be a more common baseline in others. For reference, the study abroad program for our university is located in northern Italy, and we are teaching during the full fall semester. The region has a fairly mild climate in the autumn, which means that for the majority of the months, very little energy is spent to heat or cool the large, load-bearing masonry apartment building. As in our permanent home, we live together in approximately 1,000 square feet in a multifamily building. Our permanent home is located in the more challenging climate of central Florida, where a substantial portion of the autumn requires de-humidification and cooling to maintain a comfortable and safe interior environment. 
At home, we share one small gasoline-powered automobile, and carpool to the majority of destinations. The vehicle achieves on average approximately $30 \mathrm{mpg}$. Examining the mileage of the vehicle over the last two years, our daily commute is approximately six miles per day. We do not have a vehicle abroad, and instead rely on our feet or our aged Italian bicycles to take us to and from our routine, daily destinations. Our journey to our study abroad location included a vehicle trip to the airport, a long-haul flight across the Atlantic, a short-haul flight within Europe and a taxi ride from the major airport to our apartment. This journey will be reversed for the return trip. While staying abroad, we travel with the students on three major trips within Europe. The first trip is by mini-bus, the second is by short-haul flight, and the final trip is by a combination of regional rail and high-speed rail.

When considering just the impacts of required travel, we assumed that the carbon of the necessary flights would be immense, and also assumed that our relatively small daily vehicular commute in our home city would not be comparable to these large, energy intensive journeys. Although the initial assumptions about the carbon footprint of the flights were confirmed, the impact of the daily automobile commute was severely under-estimated. If the total carbon footprint of our vehicular commute is assigned to a single individual, the shocking reality is that our footprint for travel is nearly identical for our four months abroad as it is during our four months in Florida. As noted above, we do carpool for the vast majority of journeys at home. As such, we could split the carbon footprint of our vehicle journeys between us. This is an instance where we would assume that the average American participant in a study abroad experience would differ from our circumstances. Since the average number of occupants for work travel in the United States is 1.1, and the average number for all trips is 1.5 , it is likely that the carbon footprint for travel for most participants would be at least equal to their carbon footprint while living in a similar car-free abroad situation. As the average American commute time is just over 25 minutes, when compared to our 13 minute commute, it is likely that most Americans drive farther and drive alone more of the time than we do. As such, it is reasonable to assume that most American participants in study abroad programs who routinely drive an automobile in the United States would actually lower their carbon footprint, some quite substantially, by living abroad.

\section{WHAT IS THE PROBLEM?}

As discussed in the earlier segments of this paper, some of the initial concerns were not borne out by the deeper investigations. For instance, the carbon section of the research resulted in an indictment of the sedentary, solitary, vehicular-dependent lifestyle that is the norm in the majority of the United States. It suggests that, from an energy and carbon perspective, the world would be far better off if most Americans committed to indefinite study abroad in a non-vehicular dependent society! In other instances, the concerns of the initial investigation were shown to be terribly inadequate. Access to the learning experiences of a study abroad experience remains very limited. Using the term "the one percent" actually fails to recognize how limited the access to studying abroad is, with the current access at approximately one-fifth of one percent. Closely tied to the problem of access is the cost of participation. Costs of travel and lodging make a one-semester study abroad experience equivalent to an entire year of schooling closer to home. Finally, the impact on the communities and fabric of the locations visited on study abroad experiences has taxed many of the most desirable locations in the world to the point of physically, socially and culturally placing them on the verge of destruction.

\section{HOW DO WE LESSEN THE PROBLEM?}

The question seems to be: can we lessen the burden on the communities and people we want to visit while increasing access for students and decreasing costs? In his 2010 documentary, The Cave of Forgotten Dreams, Werner Herzog confronts some of these issues and can potentially serve as a mentor. The film brings viewers into the Chauvet Cave near Vallon-Pont-d'Arc in southern France. The cave contains the oldest human drawings yet discovered, but it also contains extremely high levels of carbon dioxide and radon. Access to the cave and the drawings within is very limited, with special permission required for research projects. Herzog used, for the time, cutting-edge 3-dimensional recording technology to create a film to make the experience of the caves widely available and affordable, while adhering to the policy of limited access that will preserve the caves for future study.

In more current technology, the ability to record people and spaces with virtual reality equipment could allow a much wider audience of students to experience the world through a virtual study abroad. The motto of one such virtual reality interface, the Oculus Rift, reads, "Making it possible to experience anything, anywhere, through the power of virtual reality." This prospect could answer several of the challenges by lowering costs, increasing access and decreasing negative impacts on desirable study abroad locations. A further benefit to students would be the potential to curate a collection of experiences led by top experts in fields related to each location. This proposal, while offering the possibility of a high-quality primary experience, does lose many of the secondary experiences that were described as the actual benefit of study abroad by many experts. The immersion in another culture and language would not be possible, and the serendipitous discovery of people, places and experiences along a route personally traveled would be lost. In weighing the costs and benefits, and considering the beneficiaries and those who pay the price, perhaps innovative technology combined with better practices for travel can begin to answer some of the questions and concerns raised herein. 


\section{A FINAL OBSERVATION}

Our program is based in Vicenza, Italy "The City of Palladio." In addition to a large compliment of Palladio's works, a convenient situation between Verona and Venice, and easy access to many prominent projects by Carlo Scarpa, Vicenza has an unexpected value. Vicenza is relatively small and relatively sleepy, with few tourists. Unlike the afore-mentioned cites, and Florence, which was particularly packed with huge numbers of American students, Vicenza lives like a traditional Italian city. Experiencing the pace of life and the cultural norms of the city, where English is seldom heard and Riposo, Italy's version of the mid-day siesta, is strictly observed, offered our students a deeper understanding of living abroad and encouraged them to push themselves to embrace the full experience. Locating study abroad programs outside of traditional "marquee" cities can offer benefits equal to or perhaps exceeding immediate access to the canonical works of art and architecture. Certainly, smaller, less popular cities can offer opportunities for more immersive and authentic experiences without the crowds and commercialism that can insulate us from the very culture we travel to experience.

\section{ENDNOTES}

1 "Study Abroad Programs," Association of Collegiate Schools of Architecture, accessed September 16, 2017, http://www.acsa-arch.org/about/ special-programs/study-abroad-programs

2 "Table 310.10 Number of U.S. students studying abroad and percentage distribution, by sex, race/ethnicity, and other selected characteristics: Selected years, 2000-01 through 2013-14," National Center for Education Statistics, accessed September 18, 2017, https://nces.ed.gov/programs/digest/d15/ tables/dt15_310.10.asp

3 National Center for Education Statistics, Table 310.10.

4 National Center for Education Statistics, Table 310.10.

5 National Center for Education Statistics, Table 310.10.

6 "Table 306.10 Total fall enrollment in degree-granting postsecondary institutions, by level of enrollment, sex, attendance status, and race/ethnicity of student: Selected years, 1976 through 2014," accessed September 18, 2017, https://nces.ed.gov/programs/digest/d15/tables/dt15_306.10.asp.

7 "Table 304.10 Total fall enrollment in degree-granting postsecondary institutions, by state or jurisdiction: Selected years, 1970 through 2014," accessed September 18, 2017, https://nces.ed.gov/programs/digest/d15/tables/ dt15_304.10.asp.

8 National Center for Education Statistics, Table 310.10.

9 "Tuition Costs of Colleges and Universities," National Center for Education Statistics, accessed September 18, 2017, https://nces.ed.gov/fastfacts/display. asp?id=76.

10 Chamie, Joseph, "Student Debt Rising Worldwide," May 18, 2017, http://yaleglobal.yale.edu/content/student-debt-rising-worldwide.

11 College Tourist, "The Value of Study Abroad. \#StudyAbroadBecause", Huffington Post, 04/19/2016, http://www.huffingtonpost.com/college-tourist/ the-value-of-study-abroad_b_9729592.html.

12 "Studying Abroad: The Benefits", Top Universities, 9/11/2014, https://www. topuniversities.com/student-info/studying-abroad/studying-abroad-benefits.

13 "What others say about the value of study abroad...", NC State University, accessed September 20, 2017, https://studyabroad.ncsu.edu/for-students/ why-study-abroad/what-others-say-about-the-value-of-study-abroad/

14 Pallasmaa, Juhani, Eyes of the Skin: Architecture and the Senses. West Sussex: Wiley-Academy, 2007. Print.

15 "Why Tourism In Venice Is Doing More Harm Than Good And What We Can Do About It" Venezia Autentica, accessed September 22, 2017, http:// veneziaautentica.com/why-tourism-in-venice-is-doing-more-harm-thangood-and-what-we-can-do-about-it/

16 Burgen, Stephen, "Barcelona marches to curb negative effects of tourism", The Guardian, 01/29/2017, boomhttps://www.theguardian.com/world/2017/ jan/29/barcelona-residents-protest-high-rents-fuelled-by-tourism
17 "Tourists in Rome: data and numbers of 2015 and early 2016", Redazione Nèa Polis, January 10, 2017, http://www.neapolisroma.it/ tourists-in-rome-data-and-numbers-2015-2016/

18 "Why Tourism In Venice Is Doing More Harm Than Good And What We Can Do About It."

19 Tanner, Kristi, "Detroit's Population Still Down, Despite Hopes", May 25, 2017, http://www.freep.com/story/news/2017/05/25/ new-census-data-show-detroits-population-decline-continues/341336001/

20 "7 Most Endangered: Venice Lagoon, Italy," Europa Nostra, December 10, 2015, http://7mostendangered.eu/2015/12/10/venice-lagoon-italy/

21 Rodriquez, Cecilia, "Blacklisting Venice To Save It From Too Many Tourists And Too Few Venetians", Forbes, May 29, 2017, https://www.forbes.com/sites/ ceciliarodriguez/2017/05/29/blacklisting-venice-to-save-it-from-too-manytourists-and-too-few-venetians/\#66c92a5a1e50

22 McLaughlin, Karl, "Anti-tourism attacks in Spain: Who is behind them and what do they want?", Independent, August 10, 2017, http://www.independent. co.uk/voices/spain-attacks-anti-tourism-british-tourists-visit-barcelonamajorca-valencia-san-sebastian-a7886371.html

23 McLaughlin

24 McLaughlin.

25 Burgen.

26 Kington, Tom, "Vatican in row over 'drunken tourist herds' destroying Sistine Chapel's majesty", The Guardian, September 29, 2012, https://www.theguardian.com/world/2012/sep/29/sistine-chapel-tourist-row.

27 Kington.

28 Kington.

29 Kington, Tom, "Sistine Chapel tourists to be vacuumed and cooled to protect frescoes", The Guardian, December 21, 2012 https://www.theguardian.com/ world/2012/dec/21/sistine-chapel-tourists-vacuumed-cooled.

30 "Quick Carbon Footprint Estimate," Cool Climate Network, University of California, Berkeley, accessed September 18, 2017 